\title{
Habitat differentiation in the threatened aquatic plant genus Baldellia (L.) Parl. (Alismataceae): Implications for conservation
}

\author{
Gregor Kozlowski ${ }^{\mathrm{a}, *}$, Diethart Matthies ${ }^{\mathrm{b}}$ \\ ${ }^{a}$ Department of Biology and Botanical Garden, University of Fribourg, Chemin du Musée 10, CH-1700 Fribourg, Switzerland \\ ${ }^{\mathrm{b}}$ Department of Biology, Plant Ecology, University of Marburg, Karl-von-Frisch-Strasse 8, D-35043 Marburg, Germany
}

\begin{abstract}
A B S T R A C T
A comparative analysis of the habitats of Baldellia ranunculoides (subsp. ranunculoides and subsp. repens) and Baldellia alpestris (Alismataceae) was carried out across central and western Europe. Soil samples from 43 populations were analyzed and the composition of accompanying vegetation was analyzed by canonical correspondence and indicator species analysis. Significant differences in the habitat conditions and the accompanying vegetation were found between the three taxa. B. ranunculoides subsp. repens is growing in lowland water bodies on acidic substrates ( $\mathrm{pH} 5-6.3$ ) which are markedly richer in organic matter and poorer in cations, especially in $\mathrm{Ca}^{2+}$. B. ranunculoides $\mathrm{s}$. str. is also a lowland taxon, but grows on more mineral and basic substrates (pH 7-9), usually rich in $\mathrm{Ca}^{2+}$. The endemic $B$. alpestris grows in the most distinct habitats, on substrates with low $\mathrm{pH}$ and with very low $\mathrm{Ca}^{2+}$ concentrations, at much higher altitudes than the other taxa and in very specific plant communities that have almost no affinities with those of the two lowland Baldellia-taxa. The Baldellia-taxa are threatened by eutrophication of their habitats. Moreover, many of the extant populations, in particular those of $B$. ranunculoides s. str., are very small and will be threatened by environmental stochasticity. Reintroduction and the creation of new populations might reduce the risk of extinction. Information given on the detailed habitat preferences of the Baldellia-taxa could help conservation efforts for these endangered taxa and identify suitable sites for (re-) introductions.
\end{abstract}

\section{Introduction}

Aquatic ecosystems and in consequence aquatic organisms have been affected by multiple anthropogenic pressures (Egertson et al., 2004). Rivers have been strongly regulated, many ponds have been destroyed and ponds as well as lakes have been affected by nutrient enrichment (Roelofs, 1983; Cronk and Fennessy, 2001; Preston and Croft, 2001). As a consequence, in many countries aquatic plants are among the most threatened groups of organisms (Moser et al., 2002). The species of the genus Baldellia are no exception, having strongly declined throughout their area of distribution due to habitat destruction, fragmentation and other anthropogenic changes (Preston and Croft, 2001; Jones, 2006) and they are now threatened in many European countries (e.g. Korneck et al., 1996; Aronsson, 1999; Wigginton, 1999; Moser et al., 2002).

Baldellia is one of several small genera of the exclusively aquatic family Alismataceae (Cook, 1990). There are only two generally recognized species in the genus: B. ranunculoides (L.) Parl. (=B.

\footnotetext{
Corresponding author. Tel.: +41 2630088 42; fax: +4126 3009740

E-mail address: gregor.kozlowski@unifr.ch (G. Kozlowski).
}

ranunculoides s.str.), native to Europe and the Mediterranean and $B$. alpestris (Coss.) Vasc., endemic to the mountains of northern Portugal and northwestern Spain (Vasconcellos, 1970; Cook, 1983; Moreno Saiz and Sainz Ollero, 1992). Many studies have recognized, however, a third taxon, either called $B$. ranunculoides subsp. repens (Lam.) A. Löve \& D. Löve or B. repens (Lam.) van Ooststroom, with a more Atlantic distribution (e.g. Lawalrée, 1959; Van Rompaey and Delvosalle, 1972; Cools, 1989; Ingelög et al., 1991; Lid and Lid, 2005). Numerous differences in the morphology, genetics, vegetative growth, resource allocation and phenology support the taxonomic separation of subsp. ranunculoides and subsp. repens (Glück, 1905; Casper and Krausch, 1980; Vuille, 1988; Triest and Vuille, 1991; Preston and Croft, 2001; Jacobson, 2003).

To help the conservation of a taxon, information on its distribution, habitat preferences and biology is needed. Very little, however, is known about the ecology of the Baldellia-taxa. This is particularly true for $B$. alpestris, but also for the subsp. repens, which was often not differentiated from $B$. ranunculoides s.l. in the past. The anatomy and morphology of the genus has been described by Glück $(1905,1906)$, the reproductive biology of all three Baldellia-taxa has been studied by Vuille (1988) and their 
genetics by Triest and Vuille (1991) and Jacobson (2003). More detailed studies on the biology of the subsp. repens have been carried out only on a local scale, e.g. in Belgium (Lawalrée, 1959), in Scandinavia (Lindblad and Stahl, 1989, 1990) and in the United Kingdom (Jones, 2006).

We carried out a detailed comparative study of the habitat preferences of the three Baldellia-taxa in western and central Europe and the plant communities in which they occur. Our aims were to: (1) analyze differences in the ecological niche of the three taxa, and (2) provide a basis for more effective conservation measures and priorities.

\section{Methods}

\subsection{Study species}

All Baldellia-taxa are stoloniferous, perennial (rarely annual), rooted water plants, usually $5-30 \mathrm{~cm}$ tall (Vuille, 1988; Preston and Croft, 2001) that grow in lakes, ponds and slow streams. The three Baldellia-taxa can be differentiated by their morphology (Lawalrée, 1959; Casper and Krausch, 1980; Vuille, 1988; Triest and Vuille, 1991; Franco and Afonso, 1994). B. alpestris differs from $B$. ranunculoides s.l. in having smaller and more elliptical leaves (maximum size of leaf blades of $B$. ranunculoides s.l.: $2 \times 10 \mathrm{~cm}$; $B$. alpestris: $1 \times 5 \mathrm{~cm}$ ) with a blunt apex; it has smaller petals (maximum length $6 \mathrm{~mm}$; B. ranunculoides s.l.: 6-15 mm) and fewer nutlets (maximum 20; B. ranunculoides s.l.: 20-45). The most important characteristics for the differentiation of $B$. ranunculoides subsp. ranunculoides and subsp. repens in the field are: (1) The general habit and vegetative modus of reproduction. Subspecies ranunculoides is an erect plant without runners, whereas subsp. repens is a creeping plant with runners and has inflorescences that are rooting at the nodes. (2) The number of flowers per pseudowhorl, which is mostly $10-20$ for subsp. ranunculoides and only 2-3 for subsp. repens. (3) The surface of nutlets is smooth in subsp. ranunculoides and papillous in subsp. repens.

$B$. ranunculoides s.str. and $B$. alpestris are outcrossing but selfcompatible, whereas subsp. repens is strongly self-incompatible. $B$. ranunculoides subsp. repens has the typical characteristics of an insect-pollinated plant with high-contrast floral elements (showy pink or purple petals and yellow anthers). B. ranunculoides s.str. and B. alpestris have smaller and less contrasted flowers (Vuille, 1988).

B. ranunculoides s.str. is an Atlantic/west Mediterranean taxon (Markgraf, 1981) growing mainly in coastal regions of western Europe and the Mediterranean (Meusel et al., 1992; de Bolos and Vigo, 2003). The exact distribution of $B$. ranunculoides subsp. repens is not known. It appears to be restricted to the more Atlantic regions of western and northern Europe and to some fairly isolated sites in the western Mediterranean (Lawalrée, 1959). Its main centre of distribution, where it appears to be more frequent than subsp. ranunculoides, is probably in western and central France (e.g. Sologne, Forêt d'Orléans), Belgium and The Netherlands (e.g. Limburg; Casper and Krausch, 1980; Dupont, 1990).

B. alpestris is an endemic of northern Portugal and northwest Spain. It is occurring in mountainous regions of Asturia and Leon in Spain and of Tras-os-Montes and Minho in Portugal, as well as in some coastal regions of Beira and Alto Alentejo (Portugal; Casper and Krausch, 1980; Cook, 1983; Franco and Afonso, 1994). Romero et al. (2003) reports it also from coastal regions of Galicia and northern parts of the Sistema Iberico mountains between Burgos and Soria.

In central and western Europe B. ranunculoides s.str. is a characteristic species of the class Littorelletea uniflorae, and it can be found in all its principal alliances (Pott, 1995; Schubert et al.,
1995). B. ranunculoides subsp. repens was described as a characteristic species of the Eleocharitetum multicaulis (alliance Eleocharition multicaulis, class Littorelletea; Casper and Krausch, 1980) or of the Eleocharitetum acicularis (alliance Eleocharition acicularis, class Littorelletea) (Schoof-van Pelt, 1973). B. alpestris is usually classified as an element of the Sparganio-Glycerion (class Phragmitetea) (Sardinero Roscales, 1994) or as a species of the class Isoëto-Nanojuncetea (Casper and Krausch, 1980).

\subsection{Data collection}

The survey was carried out in the habitats of all three Baldelliataxa in the years 2005-2006 at the height of the growing season (June/August). We have inspected more than 100 localities where one of the Baldellia-taxa was indicated in the available literature or by herbarium data. We found Baldellia in less than half of the visited sites. Altogether, 43 populations in nine European countries were sampled and analyzed: 19 of $B$. ranunculoides s. str., 15 of subsp. repens and 9 of $B$. alpestris (see Fig. 1 and Appendix A). In a few large water bodies more than one population was sampled if they were separated by a distance of at least $2 \mathrm{~km}$. The species and subspecies of Baldellia were determined according to the detailed keys of Triest and Vuille (1991) and Jones (2006). At each Baldellia site we recorded the altitude, measured the depth of the water, recorded all accompanying species, estimated population size, and took samples of the substrate for chemical analyses. Because at many of the sites the Baldellia plants grew under semi-dry conditions, a physico-chemical analysis of the water was not carried out. Nomenclature for Baldellia-taxa follows Casper and Krausch (1980), for co-occurring plants Flora Europaea (Tutin et al., 1980). The schematic distribution map in Fig. 1 (inset) is based on Cook (1983), Hulten and Fries (1986), Meusel et al. (1992), Moreno Saiz and Sainz Ollero (1992), Franco and Afonso (1994), de Bolos and Vigo (2003), and Romero et al. (2003).

\subsection{Substrate analysis}

The substrate samples were collected from the root layer (c. $15 \mathrm{~cm}$ below the surface). From each site six randomly taken subsamples were pooled (final mass: c. $500 \mathrm{~g}$ ), mixed and stored at $4{ }^{\circ} \mathrm{C}$ for $5-10$ days until they were analyzed. The analyses were carried out using the standard methods developed by the Swiss Federal Research Station of Agroecology and Agriculture (FAL, 2003). The substrate samples were first homogenized manually and grained with a SK-100 crusher (Retsch Technology, Haan, Germany). The dry matter content of the samples was determined by drying the samples at $105^{\circ} \mathrm{C}$ to constant weight. Organic matter content was assessed by ignition of dry matter at $500{ }^{\circ} \mathrm{C}$ to constant weight for $1.5-3 \mathrm{~h}$. Total $\mathrm{N}$ was measured by Kjeldahl's method. The carbon-to-nitrogen $(\mathrm{C} / \mathrm{N})$ ratio was calculated as follows: organic matter content $\times 0.58 /$ total $\mathrm{N}$ (FAL, 2003). For further analysis the samples were dissolved in $20 \mathrm{ml}$ of $1: 1 \mathrm{HCl}$. After $2 \mathrm{~h}, 80 \mathrm{ml}$ of hot demineralized water was added and the solution was placed for 20 min into a boiling water bath. After cooling to ambient temperature the quantity of extracted solution was adjusted to $200 \mathrm{ml}$ and filtered. The content of $\mathrm{P}$ was determined spectrophotometrically (spectrophotometer UV/VIS 916 AA, GBC Scientific Equipment, Dandenong, Australia) by the ammonium molybdate method (wavelength $436 \mathrm{~nm}$ ) and represented as $\mathrm{P}_{2} \mathrm{O}_{5}$ content (conversion factor: $\mathrm{P} \times 2.294=\mathrm{P}_{2} \mathrm{O}_{5}$ ). The $\mathrm{K}$-content was assessed by flame spectrophotometry and represented as $\mathrm{K}_{2} \mathrm{O}$ (conversion factor: $\mathrm{K} \times 1.205=\mathrm{K}_{2} \mathrm{O}$ ). $\mathrm{Ca}^{2+}$ and $\mathrm{Mg}^{2+}$ contents were determined with an atomic adsorption photometer (UV/VIS 906 AA, GBC Scientific Equipment). The contents are expressed in $\mathrm{g} / \mathrm{kg}$ of dry matter. The $\mathrm{pH}$ was measured in a water/ 


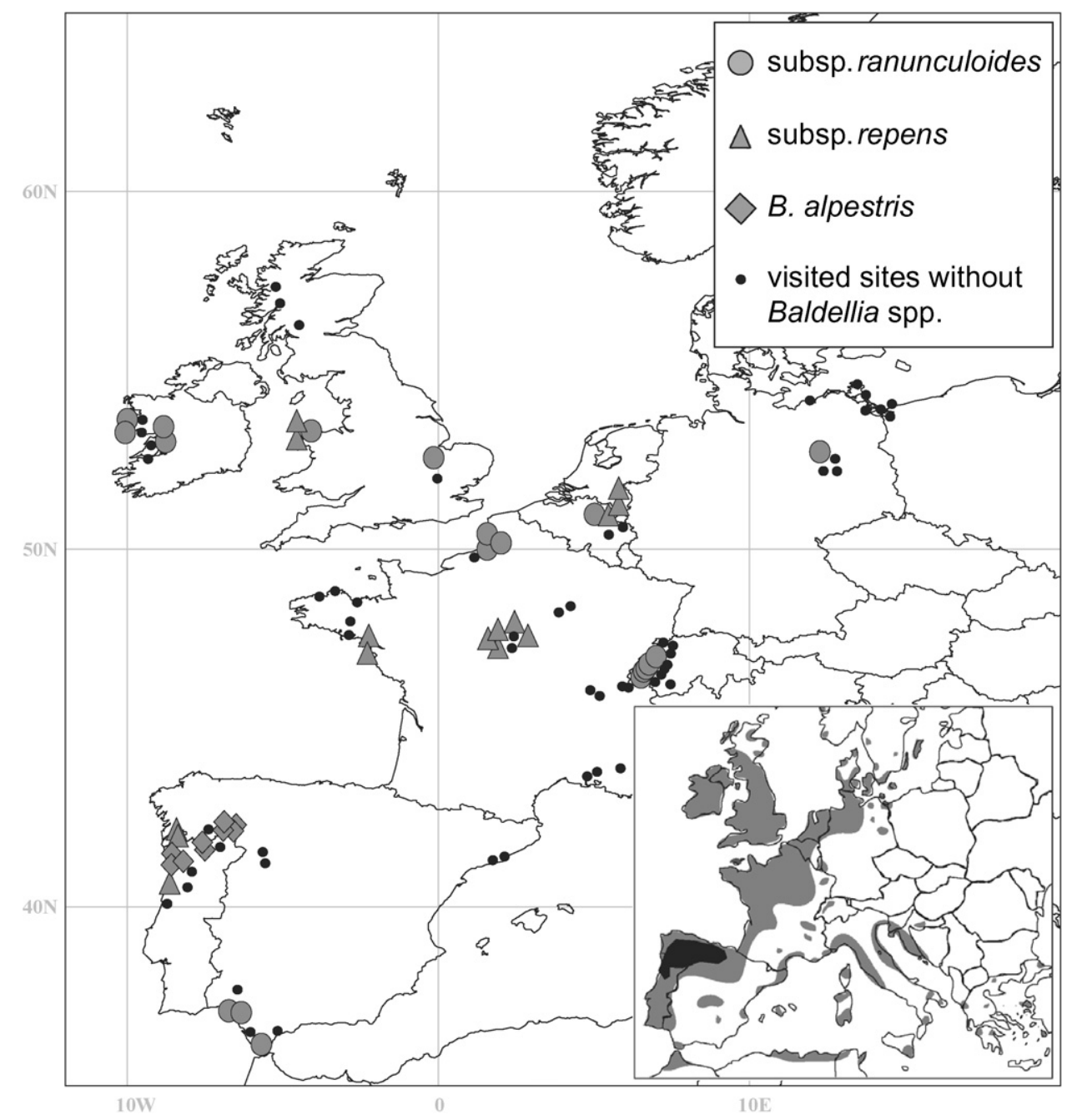

Fig. 1. Geographical location of the Baldellia-sites investigated in this study (see also Appendix A). Inset: schematic representation of the global distribution of B. ranunculoides s. str. (grey) and the narrow endemic B. alpestris (black). The detailed distribution of B. ranunculoides subsp. repens is unknown (probably very similar to subsp. ranunculoides, but the subspecies is absent in the eastern Mediterranean).

substrate suspension $(1: 2.5, \mathrm{w} / \mathrm{v})$ using a glass electrode $\mathrm{pH}$-meter (CG 842, Schott Instruments, Mainz, Germany). Electrolytic conductivity in water/substrate suspensions $(1: 5, \mathrm{w} / \mathrm{v})$ was measured using a Metrohm 712 conductimeter (Metrohm, Buckingham, UK) with a platinum electrode and platinum temperature Pt100 sensor (platinum sensor with $100 \Omega$ nominal resistance at $0{ }^{\circ} \mathrm{C}$ ).

\subsection{Statistical analysis}

The environmental conditions at the sites of the three Baldelliataxa were compared by Kruskal-Wallis one-way analyses of variance, with $p$-values calculated by the Monte-Carlo permutation test available in SPSS 12.0 (10,000 runs). If the Kruskal-Wallis test was significant, pairwise comparisons (post hoc tests) were carried out using the Tukey method, which compares $U$-values obtained in pairwise $U$-tests with critical values based on the studentized range (Sokal and Rohlf, 1995). To study whether not only the mean values for the environmental variables differed between the Baldellia-taxa, but also their variances, we tested the homogeneity of variances with the Levene Statistic.

A preliminary detrended correspondence analysis (DCA) indicated long gradients in the vegetation at the habitats of the three Baldellia-taxa (1st axis: 6.1 S.D.), and following Lepš and Šmilauer (2003) the vegetation data were therefore analyzed using unimodal instead of linear models. The vegetation was analyzed by correspondence analysis (CA), and the differences among the vegetation accompanying the Baldellia-taxa were analyzed by means of a canonical correspondence analysis (CCA) with the presence of the Baldellia-taxa as explanatory variables. The significance of the differences in vegetational composition was tested with Monte-Carlo tests (9999 permutations; CANOCO for Windows 4.5, Ter Braak and Šmilauer, 2002). Cover values were $\log -(x+1)$ transformed prior to analysis, as were most environmental variables. Downweighting of rare species was used to avoid outliers, but results of analyses without downweighting were qualitatively the same.

The explanatory power of the environmental variables recorded for the differences in the vegetation of the sites was studied by a CCA. Forward selection, using partial Monte Carlo permutation tests $(p<0.05)$ as available in CANOCO for Windows 4.5 (Ter Braak and Šmilauer, 2002), was used to identify the environmental variables in the final model. The cover values for the Baldellia-taxa were excluded from all analyses of the vegetation.

To find plant species that are typical for sites with individual Baldellia-taxa, an indicator species analysis (Dufrêne and Legendre, 
1997) was carried out. The indicator values obtained combine measures of the relative abundance and relative frequency of species (Dufrêne and Legendre, 1997). The significance of the indicator species was tested using the Monte-Carlo test available in PC-ORD (McCune and Mefford, 1999), using 10,000 permutations.

\section{Results}

\subsection{Environmental conditions}

There were clear differences in the habitat preferences of the three Baldellia-taxa (Fig. 2). Moreover, the taxa also differed in the width of their ecological niche with respect to several habitat variables, as indicated by significantly different variances (Table 1 ). The sites with $B$. ranunculoides s.str. differed from those of the other two taxa in that they had on average a higher $\mathrm{pH}$ and a higher $\mathrm{Ca}^{2+}$ and $\mathrm{Mg}^{2+}$ content (Fig. 2c, $\mathrm{k}$ and $\mathrm{l}$ ). However, the range of $\mathrm{Ca}^{2+}$ concentrations found at sites with $B$. ranunculoides s.str. was wide and the taxon also occurred at sites with hardly any calcium (sites 4, 6-8, 13, 19; see Appendix A). Sites with B. ranunculoides s.str. also had a higher dry matter but a lower organic matter content
(Fig. 2e and f), and lower total $\mathrm{N}$ concentrations (Fig. 2g) than those with the other two taxa.

While $B$. ranunculoides s.str. and subsp. repens were observed exclusively in the lowlands; $B$. alpestris appears to be a species of mountains (Fig. 2a). However, it has a wider altitudinal range than the other taxa (see Table 1) and can also occur at low altitudes. While $B$. ranunculoides s.str. and subsp. repens were exclusively taxa of shallow water ( $<20 \mathrm{~cm}$ deep), B. alpestris grew in a much wider range of water depths (Fig. $2 \mathrm{~b}$ and Table 1 ) and occurred in water up to $60 \mathrm{~cm}$ deep. A lower $\mathrm{Mg}^{2+}$ content (Fig. 2l) was the only site characteristic that was special for $B$. ranunculoides subsp. repens. The substrate in which the three taxa were growing did not differ significantly with respect to conductivity, $\mathrm{C} / \mathrm{N}$ ratio, and phosphate content (Fig. 2d, h and i).

The size of the populations of the three taxa differed (see population sizes in Appendix A). At some sites both B. alpestris and the subsp. repens were found to form almost monospecific stands of more than 10,000 individuals. In the case of the subsp. repens $\mathrm{c}$. $40 \%$ of the studied populations were larger than that number. In contrast, most populations of $B$. ranunculoides s.str. were small or medium-sized and only two populations consisted of more than 1000 individuals.
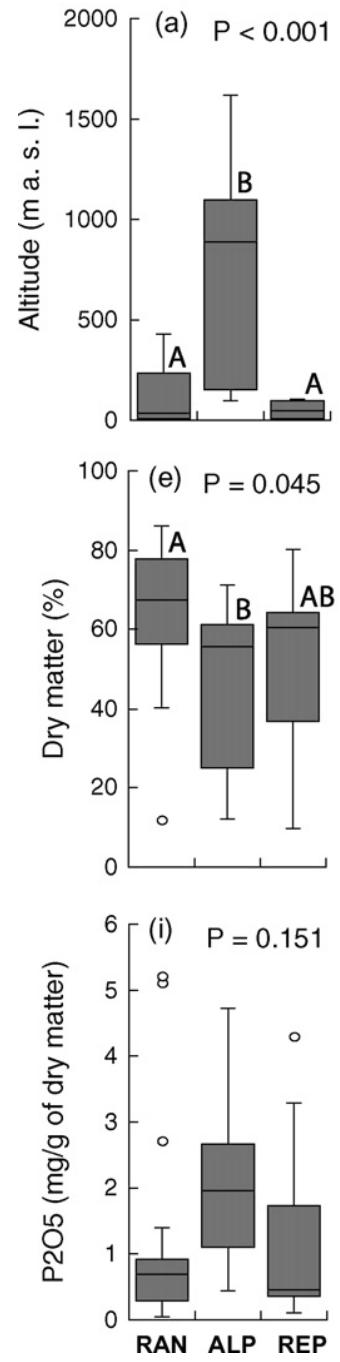
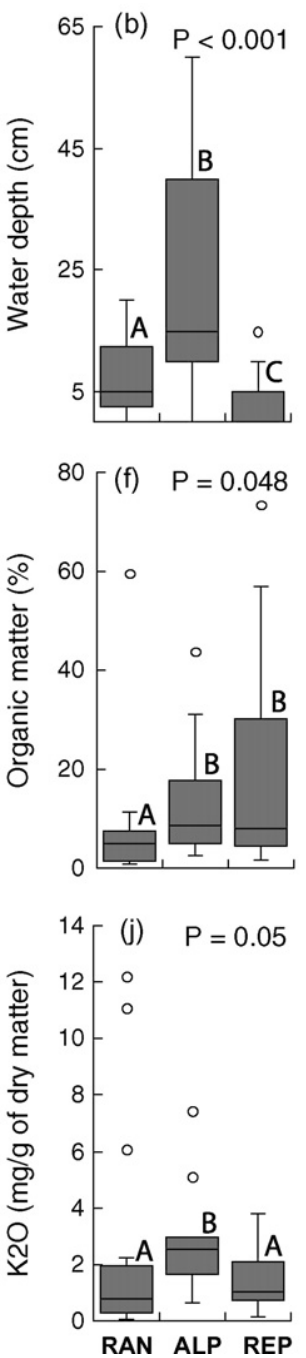
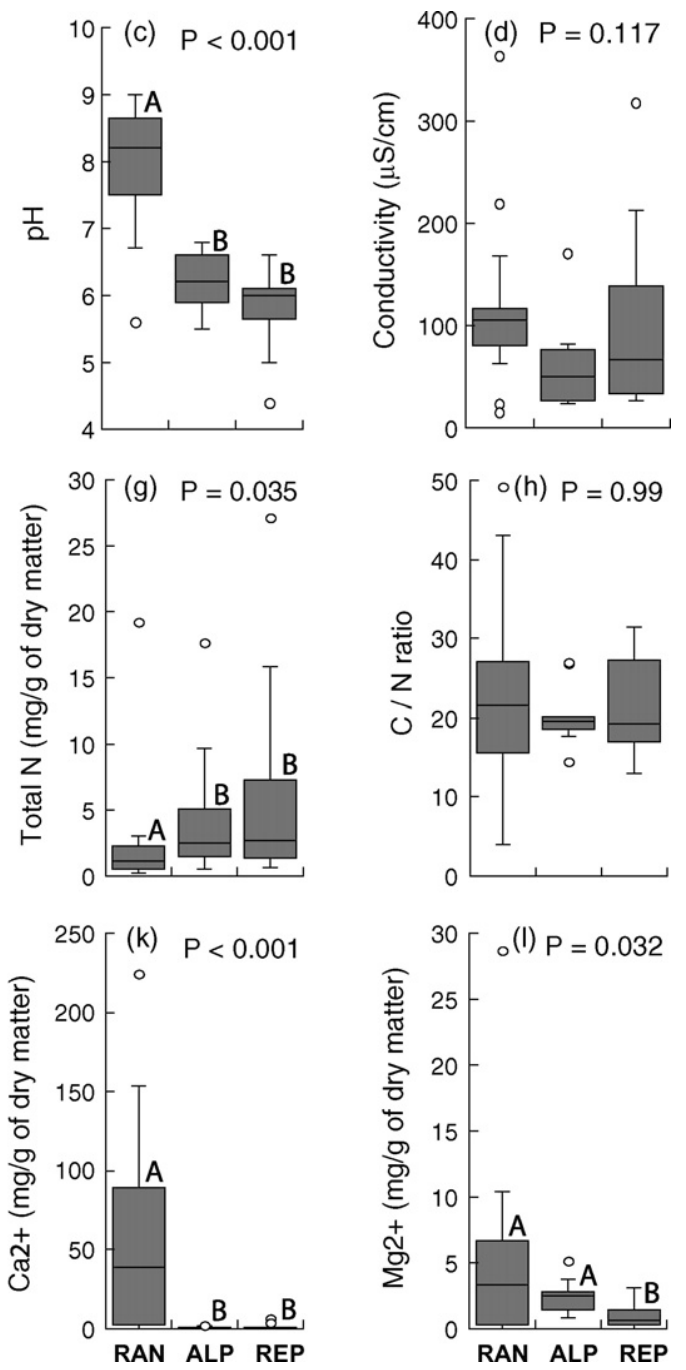

Fig. 2. Habitat conditions of the three Baldellia-taxa. Box plots indicate the median and the 25 th and 75 th percentiles of the observed distribution of measurements of 12 environmental variables in the habitats of each taxa. Whiskers indicate maximum and minimum values, circles are outliers. $P$-values for the differences among the taxa are results of Kruskal-Wallis one-way-ANOVAs with Monte-Carlo permutation tests (10,000 runs). Bars with different capital letters on top indicate individual taxa that are significantly different at the 0.05 level (Tukey method). RAN: Baldellia ranunculoides s. str.; ALP: B. alpestris; REP: B. ranunculoides subsp. repens. 
Table 1

Test of homogeneity of variances (Levene statistic) among the three Baldellia-taxa of the distribution of the environmental and substrate variables used for further analysis

\begin{tabular}{lrr}
\hline Variable & Levene statistic & $P$-value \\
\hline Altitude & 22.201 & $<0.001$ \\
Water depth & 21.291 & $<0.001$ \\
pH & 1.881 & 0.166 \\
Conductivity & 1.126 & 0.334 \\
Dry matter & 0.497 & 0.612 \\
Organic matter & 5.476 & 0.008 \\
Total N & 3.091 & 0.056 \\
$\mathrm{C} / \mathrm{N}$ ratio & 3.756 & 0.032 \\
$\mathrm{P}_{2} \mathrm{O}_{5}$ & 0.001 & 0.999 \\
$\mathrm{~K}_{2} \mathrm{O}$ & 2.626 & 0.085 \\
$\mathrm{Ca}^{2+}$ & 23.580 & $<0.001$ \\
$\mathrm{Mg}^{2+}$ & 5.205 & 0.010 \\
\hline
\end{tabular}

Degrees of freedom for all variables were 2 and 40.

\subsection{Vegetation analysis and co-occurring species}

A correspondence analysis (CA) indicated that there were strong gradients in the vegetation $\left(\lambda_{1}=0.75, \lambda_{2}=0.71\right.$; proportion of total inertia $6.0 \%$ and $5.8 \%$ ) and that the three Baldellia-taxa differed in the vegetation they were growing with (Fig. 3). The overall differences in the vegetation were highly significant (CCA with Baldellia-taxa as explanatory variables: trace $=0.91$, $p<0.0001)$. The differences between the vegetation of the highland taxon $B$. alpestris and that of the two lowland taxa were particularly strong (trace $=0.58, p<0.0001$ ), but the vegetation at sites with $B$. ranunculoides s.str. and subsp. repens differed also significantly (trace $=0.35, p=0.0017$ ).

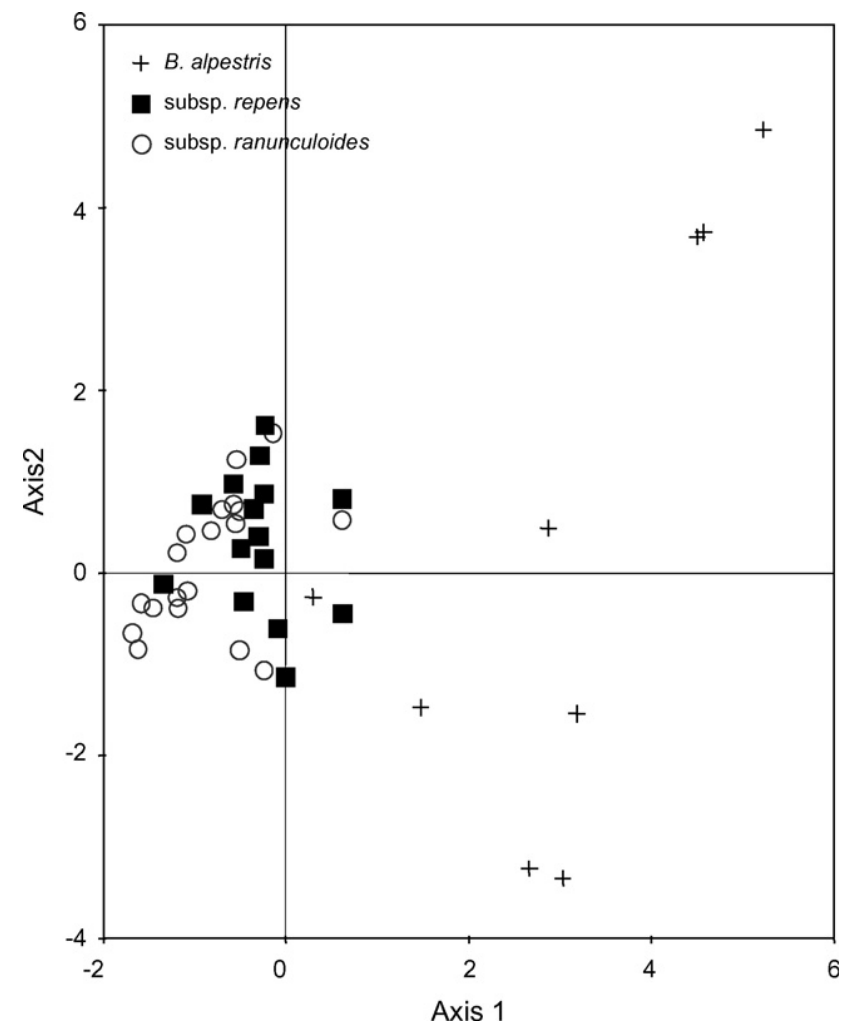

Fig. 3. CA-ordination diagram of the vegetation in which Baldellia ranunculoides s.str., subsp. repens and B. alpestris occur. Downweighting of rare species was carried out. Only site scores are shown to avoid clutter.
Table 2

Indicator species for sites with Baldellia sp.: percentage of perfect indication

\begin{tabular}{lll}
\hline & Indicator value (\%) & P-value \\
\hline $\begin{array}{lll}\text { Indicators for subsp. ranunculoides: } \\
\quad\end{array}$ & 26 & \\
Potamogeton gramineus & 26 & 0.0330 \\
Chara sp. & 26 & 0.0352 \\
Indicators for subsp. repens: & & 0.0429 \\
Galium palustre & 27 & \\
Salix sp. & 20 & 0.0296 \\
Indicators for B. alpestris: & & 0.0415 \\
Ranunculus ophioglossifolius & 67 & \\
Isoetes sp. & 33 & 0.0001 \\
Juncus heterophyllus & 33 & 0.0060 \\
Callitriche stagnalis & 32 & 0.0072 \\
Corrigiola litoralis & 22 & 0.0049 \\
Gentiana pneumonanthe & 22 & 0.0391 \\
Juncus acutiflorus & 22 & 0.0403 \\
Oenanthe crocata & 22 & 0.0402 \\
Potamogeton nodosus & 22 & 0.0407 \\
Ranunculus ololeucos & 22 & 0.0397 \\
Carum verticillatum & 22 & 0.0403 \\
\hline
\end{tabular}

The indicator values combine relative abundance and relative frequency, see Dufrêne and Legendre (1997). P-values were derived from Monte-Carlo tests of significance with 10,000 permutations.

The distinctiveness of the vegetation at sites with B. alpestris is also shown by the results of the indicator species analysis: 11 species were significantly associated with $B$. alpestris, but only three species with $B$. ranunculoides s.str. and only two species with subsp. repens (Table 2). Most of the indicator species for B. alpestris are Atlantic/west-Mediterranean phytogeographical elements (e.g. Carum verticillatum, Corrigiola litoralis, Juncus heterophyllus, Oenanthe crocata, and Ranunculus ololeucos, Table 2). The species that most frequently were associated with all three Baldellia-taxa, and not with a particular taxon, were common species in aquatic communities like Mentha aquatica, Hydrocotyle vulgaris and Eleocharis palustris (Table 3).

In a CCA-ordination of the vegetation together with the recorded environmental variables only altitude and $\mathrm{pH}$ had a significant effect on the composition of the vegetation $(p<0.05)$. The eigenvalues of the CCA-ordination $\left(\lambda_{1}=0.47, \lambda_{2}=0.33\right.$; proportion of total inertia $5.0 \%$ and $3.5 \%$ ) were lower than those of the CA-ordination, but still high and highly significant (trace $=0.799, p<0.0001$ ), indicating that $\mathrm{pH}$ and altitude explained a substantial part of the variation in vegetational composition among the sites with Baldellia. The CCA-ordination restricted by altitude and $\mathrm{pH}$ separated clearly the sites with the different Baldellia-taxa (Fig. 4). Sites with B. ranunculoides s.str. were separated from those with the other two taxa by their higher $\mathrm{pH}$, and sites with $B$. alpestris were separated, although somewhat less clearly, from the other taxa by their higher altitude.

\section{Discussion}

We found significant differences between the habitat conditions and accompanying species of the three Baldellia-taxa in central and western Europe. B. ranunculoides s.str. is a lowland species, growing on mineral and basic substrates ( $\mathrm{pH} 7-9$ ), mainly rich in $\mathrm{Ca}^{2+}$. Such calcareous habitats occur for example next to the sea shore close to $\mathrm{Ca}^{2+}$-rich dunes (e.g. sites 10-12, see Appendix A), in lakes and ponds on limestone outcrops (e.g. sites 5 and 9 ) or on $\mathrm{Ca}^{2+}$-rich substrates in pre-alpine regions (sites 1418). In regions close to the Atlantic or Mediterranean coast $B$. ranunculoides s.str. can also grow in brackish waters with salinities of $150-1850 \mu \mathrm{S} / \mathrm{cm}$ (in comparison Cladium mariscus: up to 
Table 3

Species occurring most frequently with taxa of the genus Baldellia

\begin{tabular}{ll}
\hline Species & Constancy (\%) \\
\hline Mentha aquatica & 48.8 \\
Hydrocotyle vulgaris & 37.2 \\
Eleocharis palustris & 30.2 \\
Phragmites australis & 30.2 \\
Lysimachia vulgaris & 27.9 \\
Ranunculus flammula & 27.9 \\
Hypericum elodes & 23.3 \\
Lycopus europaeus & 23.3 \\
Alisma plantago-aquatica & 20.9 \\
Molinia caerulea & 18.6 \\
Agrostis stolonifera & 14.0 \\
Juncus bulbosus & 14.0 \\
Apium indundatum & 11.6 \\
Carex rostrata & 11.6 \\
Eleocharis acicularis & 11.6 \\
Juncus articulatus & 11.6 \\
Juncus maritimus & 11.6 \\
Potamogeton gramineus & 11.6
\end{tabular}

Constancy is given as the proportion of all 43 Baldellia sites investigated in which a given species occurred (only species with constancy $>10 \%$ are listed).

$15,500 \mu \mathrm{S} / \mathrm{cm}$; Iris pseudacorus: up to $10,400 \mu \mathrm{S} / \mathrm{cm}$; Fullana Montoro, 2001), which is not the case for subsp. repens (Preston and Croft, 2001).

B. ranunculoides subsp. repens is also a taxon of lowland water bodies, but grows on acidic substrates, which are markedly richer in organic matter. Acidic peat substrates ( $\mathrm{pH}$ 5.0-6.5), with an organic matter content of more than $50 \%$ of dry matter, are colonized only by subsp. repens. It is growing on substrates, which are clearly poorer in $\mathrm{Ca}^{2+}$. Its habitats are thus similar to those of other typical Littorelletea-species of northern and eastern Europe like Luronium natans, Lobelia dortmana, Littorella uniflora, Juncus bulbosus, and Eleocharis acicularis, that grow on substrates poor in $\mathrm{Ca}^{2+}$ (0.0-3.0 mg/g; Szankowski and Klosowski, 2001; Arts, 2002; Murphy, 2002). The habitat differences are also reflected in our vegetation analysis. Schoof-van Pelt (1973), who did the most detailed vegetation analysis of all Littorelletean associations in western Europe so far, was not able to detect any differentiating species for the subspecies. Our study that covered a larger geographical area and analyzed a broader spectrum of habitats demonstrates for the first time a significant differentiation in the composition of the vegetation accompanying the two subspecies of B. ranunculoides s.l.

Our observations on habitat differentiation between the two subspecies of $B$. ranunculoides s.l. confirm and extend local observations from western Europe (Roelofs, 1983; Roelofs et al., 1984; Vuille, 1988; Arts and den Hartog, 1990; Brouwer et al., 1999; Brouwer and Roelofs, 2001; Roelofs, 2002) and the Mediterranean (Maremmani et al., 2003; Dimopoulos et al., 2005). The habitat differentiation between the taxa may also explain why in certain regions where subsp. repens is common, $B$. ranunculoides s.str. is very rare. This is the case, for example, in central France (Dupont, 1990) and in Wales (Jones, 2006) where acidic and $\mathrm{Ca}^{2+}$-poor soils predominate. However, the two subspecies of $B$. ranunculoides s.l. have not always been distinguished in the general literature (Tutin et al., 1980). Even publications devoted exclusively to aquatic plants (Cook, 1983) as well as more detailed ecological studies (Loucougaray et al., 2004), did not differentiate between the subspecies. Our results show that apart from evident morphological (Vuille, 1988) and genetic differences (Triest and Vuille, 1991; Jacobson, 2003), there are clear ecological differences between the two subspecies, suggesting that future studies and conservation efforts need to differentiate between the subspecies of B. ranunculoides s.l.

Vuille (1988) proposed that the Iberian endemic species, $B$. alpestris, is ecologically an intermediate between subsp. ranunculoides and subsp. repens. However, our study - which is the first detailed analysis of its habitat preferences - shows clearly, that it is the most distinct taxon of the genus with respect to its habitat, as indicated by both the environmental and vegetation data (in order to facilitate the comparison we have placed $B$. alpestris in Fig. 2 between both subspecies of $B$. ranunculoides). B. alpestris grows, similarly to $B$. ranunculoides subsp. repens, in habitats with low $\mathrm{pH}$ and on substrates with low $\mathrm{Ca}^{2+}$ concentrations, but it occurs at much higher altitudes (up to $1800 \mathrm{~m}$ ) and in plant communities that are very different from those supporting the two other Baldellia-taxa. B. alpestris occurs mainly in glacial lakes (sites 42-43) of the Iberian mountains where it is forming large, almost monospecific stands, along gently sloping and shallow shores. It can be found also, however, in deep artificial village ponds and in mountain streams with very steep slopes and a

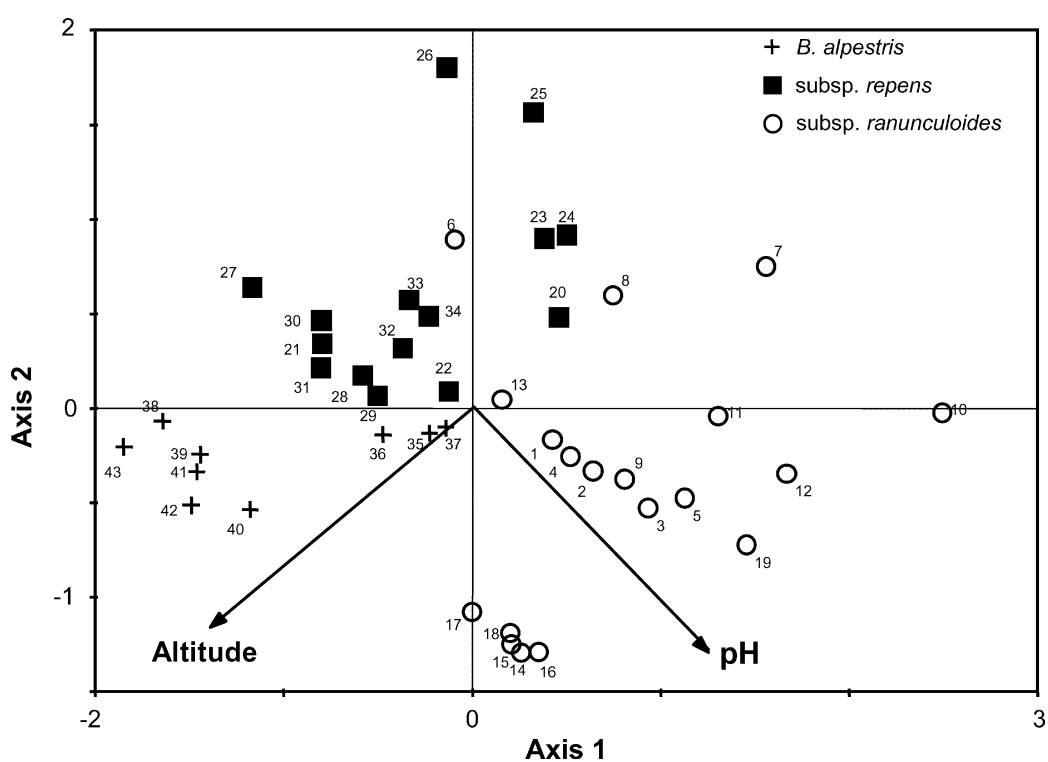

Fig. 4. CCA-Ordination diagram of the vegetation in which Baldellia ranunculoides s.str., subsp. repens and B. alpestris occur, with altitude and pH as environmental variables. Downweighting of rare species was activated. Only site scores are shown to avoid clutter. Numbers refer to the sites studied (see Appendix A). 
depth of ca. 50-100 cm (sites 35-37). Most of the indicator and co-occurring species of $B$. alpestris belong to the west-Mediterranean phytogeographical element. These species have become extremely rare or are extinct in central and northern Europe, which explains the very isolated position of $B$. alpestris in our vegetation analysis. According to Cook (1983), B. alpestris is a neoendemic species. However, in a genetic study of Triest and Vuille (1991) B. alpestris was strongly differentiated from B. ranunculoides s.l., which together with our results might suggest that $B$. alpestris is rather a paleo-endemic taxon.

There were strong differences between the three Baldellia-taxa in the structure of their populations which may be related to their mode of propagation. Subspecies repens and B. alpestris multiply clonally by inflorescence stolons of up to $0.5 \mathrm{~m}$ length, whereas $B$. ranunculoides s.str. mainly reproduces sexually, but may also exhibit some short-distance clonal growth by means of corm-buds (Vuille, 1988; Jones, 2006). Well established populations of the two clonal taxa subsp. repens and B. alpestris frequently form large, locally dominant (or even monospecific) stands. In contrast, the mainly sexual taxon $B$. ranunculoides s.str. does so only rarely and shoot density can be very low (Jones, 2006). It has been suggested that the reproductive strategy of subsp. ranunculoides, which is self-compatible, is similar to that of many annual plants (Vuille, 1988), since it invests more resources in sexual reproduction and flowers profusely.

\subsection{Implications for conservation}

The Baldellia-taxa probably are weak competitors (Cook, 1983; Preston and Croft, 2001) that grow in specific aquatic habitats, which combine oligotrophy and disturbance resulting in rather open vegetation with low biomass. The related $L$. natans has a similar habitat preference (Willby and Eaton, 1993). Eutrophication favouring fast-growing species (Casper and Krausch, 1980; Markgraf, 1981) has therefore been suggested as the most important factor for the decline of Baldellia-species and other water plants (Roelofs, 1983; Brouwer and Roelofs, 2001; Arts, 2002; Murphy, 2002; Szankowski and Klosowski, 2006). Other factors that have been suggested as possible causes of the decline of many plants of Littorelletea-communities include both acidification and alkalinization (Roelofs, 1983; Szankowski and Klosowski, 2001, 2006; Arts, 2002).

Acidification, caused mainly by anthropogenic acid rain, should be most harmful to B. ranunculoides s.str., since this taxon is growing mostly on substrates with a $\mathrm{pH}>7.0$, whereas the two other Baldellia-taxa were found frequently in acidic habitats. However, in The Netherlands negative effects of acidification on communities with both $B$. ranunculoides s.str. and subsp. repens have been observed (Roelofs, 1983). An increase in alkalinity (e.g. due to the addition of alkaline stream water used to compensate for water losses) has often been cited as a cause of the decline of Littorelletean and Isoetid species (Brouwer et al., 1999; Brouwer and Roelofs, 2001; Murphy, 2002). Our results suggest that $B$. ranunculoides subsp. repens and $B$. alpestris are restricted to habitats with a very low pH. $B$. ranunculoides s.str., in contrast, has a much broader amplitude with respect to the alkalinity of substrate and water, and could potentially be much more resistant to alkalinization. Because of this difference it is important that conservationists take the ecological and taxonomic differentiation of the two subspecies of $B$. ranunculoides into account. To date this has only been the case in Scandinavia and the Benelux countries (Lawalrée, 1959; Van Rompaey and Delvosalle, 1972; Cools, 1989; Ingelög et al., 1991; Lid and Lid, 2005).

The analysis of the size of the existing populations showed that many of the Baldellia-populations are very small. This is particularly true for $B$. ranunculoides $s$. str. Both theoretical considerations (Menges, 1991) and empirical evidence (Matthies et al., 2004) indicate that small populations of plants are threatened not only by habitat deterioration, but also by environmental, demographic and genetic stochasticity. Because the number of extant populations is small and in many regions no populations exist any longer, it is unlikely that suitable habitats will be colonized by Baldellia. The creation of new populations at suitable sites should therefore be considered (cf. Vittoz et al., 2006). The list of specific indicator species for sites with one of the taxa (Table 2) can be helpful in identifying new sites specifically suited for each taxon.

\section{Acknowledgements}

We would like to thank Benoît Clement and Susanne Bollinger from the Botanical Garden of the University of Fribourg (Switzerland) as well as Marius Achermann and Francesca Cheda from the Nature Protection Office of the Canton Fribourg (Switzerland) for their advice, financial and technical support. We are much indebted to the Franklinia Foundation for its engagement and valuable support during fieldwork. We are very grateful to the following persons for field assistance, population indications and help with species identification: André Python (University of Fribourg, Switzerland), François Dehondt (Conservatoire botanique de Franche-Comté, France), Grégory Rollion (Parc Ornithologique du Marquenterre, France), Christian Clerc (GEG ChampPittet, Switzerland), Paulo Alves and Rubim da Silva (University of Porto, Portugal), Andrew Jones (Countryside Council for Wales, UK) and Nick Millar (Cambridgeshire Wildlife Trust, UK). Comments by Jan Vermaat and two anonymous reviewers improved the text.

\section{Appendix A}

Location and short characterization of Baldellia-sites investigated in this study. Population size classes: 1: 1-100 plants; 2: 101-1000; 3: more than 1000 individuals; 4 : more than 10,000 individuals.

\begin{tabular}{|c|c|c|c|c|c|c|}
\hline Site Nr. & Site name & Country/region & Geographical coordinates & Alt. (m) & Habitat type & Population size \\
\hline \multicolumn{7}{|c|}{ B. ranunculoides subsp. ranunculoides } \\
\hline 1 & El Acebuche 1 & Spain/W Andalucia & $37^{\circ} 02^{\prime} 59.9^{\prime \prime} \mathrm{N}-6^{\circ} 34^{\prime} 11.9^{\prime \prime} \mathrm{W}$ & 37 & Lagoon & 1 \\
\hline 2 & El Acebuche 2 & Spain/W Andalucia & $37^{\circ} 02^{\prime} 54.9^{\prime \prime} \mathrm{N}-6^{\circ} 34^{\prime} 10.2^{\prime \prime} \mathrm{W}$ & 36 & Lagoon & 1 \\
\hline 3 & Facinas & Spain/E Andalucia & $36^{\circ} 09^{\prime} 19.4^{\prime \prime} \mathrm{N}-5^{\circ} 41^{\prime} 16.2^{\prime \prime} \mathrm{W}$ & 33 & Road channel & 2 \\
\hline 4 & Loch Cutry & Ireland/County Clare & $53^{\circ} 02^{\prime} 14.3^{\prime \prime} \mathrm{N}-8^{\circ} 46^{\prime} 09.6^{\prime \prime} \mathrm{W}$ & 38 & Lake shore & 3 \\
\hline 5 & Loch Blackloon & Ireland/County Clare & $53^{\circ} 09^{\prime} 41.7^{\prime \prime} \mathrm{N}-8^{\circ} 50^{\prime} 31.5^{\prime \prime} \mathrm{W}$ & 22 & Lake shore & 3 \\
\hline 6 & South of Clifden & Ireland/County Galway & $53^{\circ} 27^{\prime} 45.0^{\prime \prime} \mathrm{N}-10^{\circ} 00^{\prime} 42.8^{\prime \prime} \mathrm{W}$ & 11 & Stream shore & 2 \\
\hline 7 & Ballyconneely & Ireland/County Galway & $53^{\circ} 25^{\prime} 27.2^{\prime \prime} \mathrm{N}-10^{\circ} 04^{\prime} 25.9^{\prime \prime} \mathrm{W}$ & 1 & Lagoon & 2 \\
\hline 8 & Cors Erddreiniog & United Kingdom/Wales & $53^{\circ} 18^{\prime} 12.0^{\prime \prime} \mathrm{N}-4^{\circ} 17^{\prime} 48.0^{\prime \prime} \mathrm{W}$ & 5 & Fen border & 2 \\
\hline
\end{tabular}


Appendix A (Continued)

\begin{tabular}{|c|c|c|c|c|c|c|}
\hline Site Nr. & Site name & Country/region & Geographical coordinates & Alt. (m) & Habitat type & Population size \\
\hline 9 & Peterborough & United Kingdom/England & $52^{\circ} 33^{\prime} 08.1^{\prime \prime} \mathrm{N}-0^{\circ} 09^{\prime} 13.7^{\prime \prime} \mathrm{W}$ & 30 & Pond shore & 1 \\
\hline 10 & Ornithological Parc & France/Marquenterre & $50^{\circ} 15^{\prime} 51.5^{\prime \prime} \mathrm{N}-1^{\circ} 33^{\prime} 30.9^{\prime \prime} \mathrm{E}$ & 1 & Dune slack & 1 \\
\hline 11 & Fort-Mahon-Plage 1 & France/Marquenterre & $50^{\circ} 20^{\prime} 58.0^{\prime \prime} \mathrm{N}-1^{\circ} 33^{\prime} 45.0^{\prime \prime} \mathrm{E}$ & 7 & Dune slack & 1 \\
\hline 12 & Fort-Mahon-Plage 2 & France/Marquenterre & $50^{\circ} 20^{\prime} 54.5^{\prime \prime} \mathrm{N}-1^{\circ} 33^{\prime} 52.1^{\prime \prime} \mathrm{E}$ & 7 & Dune slack & 1 \\
\hline 13 & Platwijers & Belgium/Limburg & $50^{\circ} 58^{\prime} 15.6^{\prime \prime} \mathrm{N}-5^{\circ} 20^{\prime} 14.7^{\prime \prime} \mathrm{E}$ & 38 & Fish pond bottom & 1 \\
\hline 14 & Lac de Neuchâtel 1 & Switzerland/Canton Vaud & $46^{\circ} 47^{\prime} 09.1^{\prime \prime} \mathrm{N}-6^{\circ} 40^{\prime} 05.8^{\prime \prime} \mathrm{E}$ & 433 & Road channel & 2 \\
\hline 15 & Lac de Neuchâtel 2 & Switzerland/Canton Vaud & $46^{\circ} 47^{\prime} 12.1^{\prime \prime} \mathrm{N}-6^{\circ} 40^{\prime} 03.2^{\prime \prime} \mathrm{E}$ & 432 & Lake shore & 1 \\
\hline 16 & Lac de Neuchâtel 3 & Switzerland/Canton Vaud & $46^{\circ} 47^{\prime} 47.9^{\prime \prime} \mathrm{N}-6^{\circ} 41^{\prime} 36.5^{\prime \prime} \mathrm{E}$ & 432 & Lake shore & 1 \\
\hline 17 & Lac de Neuchâtel 4 & Switzerland/Canton Vaud & $46^{\circ} 47^{\prime} 25.8^{\prime \prime} \mathrm{N}-6^{\circ} 40^{\prime} 46.9^{\prime \prime} \mathrm{E}$ & 432 & Road channel & 1 \\
\hline 18 & Lac de Neuchâtel 5 & Switzerland/Canton Fribourg & $46^{\circ} 54^{\prime} 34.7^{\prime \prime} \mathrm{N}-6^{\circ} 56^{\prime} 20.6^{\prime \prime} \mathrm{E}$ & 432 & Lake shore & 1 \\
\hline 19 & Gülpersee & Germany/Havelland & $52^{\circ} 43^{\prime} 56.1^{\prime \prime} \mathrm{N}-12^{\circ} 15^{\prime} 28.9^{\prime \prime} \mathrm{E}$ & 21 & Lake shore & 2 \\
\hline \multicolumn{7}{|c|}{ B. ranunculoides subsp. repens } \\
\hline 20 & Paramos & Portugal/Douro Littoral & $40^{\circ} 58^{\prime} 10.7^{\prime \prime} \mathrm{N}-8^{\circ} 38^{\prime} 38.0^{\prime \prime} \mathrm{W}$ & 10 & Fen border & 1 \\
\hline 21 & Furgeira & Portugal/Minho & $41^{\circ} 46^{\prime} 04.1^{\prime \prime} \mathrm{N}-8^{\circ} 38^{\prime} 31.9^{\prime \prime} \mathrm{W}$ & 100 & Peatland & 2 \\
\hline 22 & Rio Lima & Portugal/Minho & $41^{\circ} 49^{\prime} 31.6^{\prime \prime} \mathrm{N}-8^{\circ} 19^{\prime} 31.6^{\prime \prime} \mathrm{W}$ & 55 & River shore & 1 \\
\hline 23 & Llanfairynghornwyn & United Kingdom/Wales & $53^{\circ} 23^{\prime} 54.0^{\prime \prime} \mathrm{N}-4^{\circ} 33^{\prime} 12.0^{\prime \prime} \mathrm{W}$ & 5 & Dune slack & 4 \\
\hline 24 & Fydlyn & United Kingdom/Wales & $53^{\circ} 23^{\prime} 42.0^{\prime \prime} \mathrm{N}-4^{\circ} 34^{\prime} 00.0^{\prime \prime} \mathrm{W}$ & 5 & Dune slack & 4 \\
\hline 25 & La Chap.-des-Marais & France/Brière & $47^{\circ} 26^{\prime} 31.9^{\prime \prime} \mathrm{N}-2^{\circ} 14^{\prime} 59.8^{\prime \prime} \mathrm{W}$ & 1.5 & Peatland channel & 1 \\
\hline 26 & La Pierre Fendue & France/Brière & $47^{\circ} 23^{\prime} 18.6^{\prime \prime} \mathrm{N}-2^{\circ} 17^{\prime} 44.6^{\prime \prime} \mathrm{W}$ & 2 & Peatland pond & 2 \\
\hline 27 & Etang des Brosses & France/Sologne & $47^{\circ} 30^{\prime} 16.5^{\prime \prime} \mathrm{N}-1^{\circ} 54^{\prime} 44.2^{\prime \prime} \mathrm{E}$ & 103 & Pond shore & 1 \\
\hline 28 & Etang de Bièvre & France/Sologne & $47^{\circ} 30^{\prime} 00.9^{\prime \prime} \mathrm{N}-1^{\circ} 50^{\prime} 57.1^{\prime \prime} \mathrm{E}$ & 98 & Shore of small pond & 4 \\
\hline 29 & E. la Grand Corbois & France/Sologne & $47^{\circ} 30^{\prime} 57.2^{\prime \prime} \mathrm{N}-1^{\circ} 54^{\prime} 01.4^{\prime \prime} \mathrm{E}$ & 101 & Shore of small pond & 1 \\
\hline 30 & La Noue Mazone & France/Foret d'Orleans & $47^{\circ} 54^{\prime} 42.3^{\prime \prime} \mathrm{N}-2^{\circ} 26^{\prime} 20.3^{\prime \prime} \mathrm{E}$ & 88 & Lake shore & 1 \\
\hline 31 & E. de la Grande Rue & France/Foret d'Orleans & $47^{\circ} 41^{\prime} 40.7^{\prime \prime} \mathrm{N}-2^{\circ} 52^{\prime} 42.4^{\prime \prime} \mathrm{E}$ & 105 & Lake shore & 4 \\
\hline 32 & De Maten & Belgium/Limburg & $50^{\circ} 57^{\prime} 22.4^{\prime \prime} \mathrm{N}-5^{\circ} 27^{\prime} 38.2^{\prime \prime} \mathrm{E}$ & 52 & Fish pond shore & 1 \\
\hline 33 & Lake Banen 1 & The Netherlands/Limburg & $51^{\circ} 15^{\prime} 57.4^{\prime \prime} \mathrm{N}-5^{\circ} 47^{\prime} 58.2^{\prime \prime} \mathrm{E}$ & 30 & Pond shore & 4 \\
\hline 34 & Lake Banen 2 & The Netherlands/Limburg & $51^{\circ} 15^{\prime} 50.1^{\prime \prime} \mathrm{N}-5^{\circ} 47^{\prime} 60.3^{\prime \prime} \mathrm{E}$ & 30 & Pond shore & 4 \\
\hline \multicolumn{7}{|c|}{ B. alpestris } \\
\hline 35 & Silva Escura & Portugal/Douro Littoral & $41^{\circ} 15^{\prime} 14.4^{\prime \prime} \mathrm{N}-8^{\circ} 34^{\prime} 37.2^{\prime \prime} \mathrm{W}$ & 100 & Ancient village pond & 1 \\
\hline 36 & Devesa & Portugal/Douro Littoral & $41^{\circ} 14^{\prime} 49.5^{\prime \prime} \mathrm{N}-8^{\circ} 35^{\prime} 11.5^{\prime \prime} \mathrm{W}$ & 150 & Ancient village pond & 1 \\
\hline 37 & Aqualangua & Portugal/Douro Littoral & $41^{\circ} 16^{\prime} 04.3^{\prime \prime} \mathrm{N}-8^{\circ} 29^{\prime} 43.7^{\prime \prime} \mathrm{W}$ & 100 & Stream shore & 1 \\
\hline 38 & Lake Rabagao & Portugal/Tras os Montes & $41^{\circ} 45^{\prime} 48.6^{\prime \prime} \mathrm{N}-7^{\circ} 44^{\prime} 48.2^{\prime \prime} \mathrm{W}$ & 862 & Artificial lake shore & 2 \\
\hline 39 & Lake Alto Cavado & Portugal/Tras os Montes & $41^{\circ} 48^{\prime} 05.6^{\prime \prime} \mathrm{N}-7^{\circ} 52^{\prime} 31.7^{\prime \prime} \mathrm{W}$ & 888 & Artificial lake shore & 3 \\
\hline 40 & Rio Tera & Spain/Sanabria & $42^{\circ} 07^{\prime} 12.1^{\prime \prime} \mathrm{N}-6^{\circ} 41^{\prime} 55.1^{\prime \prime} \mathrm{W}$ & 1030 & River shore & 1 \\
\hline 41 & Rio Caradena & Spain/Sanabria & $42^{\circ} 07^{\prime} 13.0^{\prime \prime} \mathrm{N}-6^{\circ} 45^{\prime} 43.4^{\prime \prime} \mathrm{W}$ & 1100 & Stream shore & 1 \\
\hline 42 & Laguna Roya & Spain/Segundera & $42^{\circ} 08^{\prime} 11.4^{\prime \prime} \mathrm{N}-6^{\circ} 47^{\prime} 38.5^{\prime \prime} \mathrm{W}$ & 1615 & Glacial lake & 4 \\
\hline 43 & Laguna del Pavon & Spain/Segundera & $42^{\circ} 07^{\prime} 56.1^{\prime \prime} \mathrm{N}-6^{\circ} 46^{\prime} 33.9^{\prime \prime} \mathrm{W}$ & 1595 & Glacial lake & 4 \\
\hline
\end{tabular}

\section{References}

Aronsson, M. (Ed.), 1999. Rödlistade kärlväxter i Sverige. vol. 1. ArtDatabanken SLU, Uppsala.

Arts, G.H.P., 2002. Deterioration of atlantic soft water macrophyte communities by acidification, eutrophication and alkalinization. Aquat. Bot. 73, 373-393.

Arts, G.H.P., den Hartog, C., 1990. Phytogeographical aspects of the West European soft-water macrophyte flora. Acta Bot. Neerl. 39, 365-370.

Brouwer, E., Roelofs, J.G.M., 2001. Degraded softwater lakes: possibilities for restoration. Restor. Ecol. 9, 155-166.

Brouwer, E., Soontiëns, J., Bobbink, R., Roelofs, J.G.M., 1999. Sulphate and bicarbonate as key factors in sediment degradation and restoration of Lake Banen. Aquat. Conserv.: Mar. Freshwat. Ecol. 9, 121-132.

Casper, S.J., Krausch, H.-D., 1980. Pteridophyta und Anthophyta. Teil 1. In: Ettl, H., Gerloff, J., Heynig, H. (Eds.), Süsswasserflora von Mitteleuropa. Band 23. VEB Gustav Fischer, Jena, pp. 157-184.

Cook, C.D.K., 1983. Aquatic plants endemic to Europe and the Mediterranean. Bot. Jahrb. 103, 539-582.

Cook, C.D.K., 1990. Aquatic Plant Book. SPB Academic Publishing, The Hague.

Cools, J.M.A., 1989. Atlas van de Noordbrabantse Flora. Stichting Uitgeverij van de Koninklijke Natuurhistorische Vereniging, Tilburg.

Cronk, J.K., Fennessy, M.S., 2001. Water Plants: Biology and Ecology. Lewis Publishers, Boca Raton.

de Bolos, O., Vigo, J., 2003. Flora dels Paisos Catalans. IV. Barcino S.A., Barcelona.

Dimopoulos, P., Sykora, K., Gilissen, C., Wiecherink, D., Georgiadis, Th., 2005 Vegetation ecology of Kalodiki Fen (NW Greece). Biologia (Bratislava) 60, 69-82.

Dufrêne, M., Legendre, P., 1997. Species assemblages and indicator species: the need for a flexible asymmetrical approach. Ecol. Monogr. 67, 345-366.

Dupont, P., 1990. Atlas partiel de la flore de France. Collection Patrimoines Naturelles. vol. 3. Série Patrimoine Génétique. Muséum National d'Histoire Naturelle, Paris.

Egertson, C.J., Kopaska, J.A., Downing, J.A., 2004. A century of change in macrophyte abundance and composition in response to agricultural eutrophication. Hydrobiologia 524, 145-156.

FAL (Eidgenossische Forschungsanstallt für Agrarökologie und Landbau), 2003. Referenzmethoden der eidgenossischen landwirtschaftlichen Forschungsan- stalten. Band 2. Bodenuntersuchungen zur Standort-Charakterisierung. FAL Reckenholz, Zürich.

Franco, J.A., Afonso, M.L.R., 1994. Nova Flora de Portugal. Fasciculo I., vol. 3. Cambridge University Press, Lisboa.

Fullana Montoro, J., 2001. Plan de protection de recursos hidricos de la zona humeda de Almenara. Varios (Castellon). Ministerio de Medio Ambiente. Oficina de planification hidrologica, Varios.

Glück, H., 1905. Biologische und morphologische Untersuchungen über Wasser und Sumpfgewächse. Erster Teil: Die Lebensgeschichte der europäischen Alismataceen. Gustav Fischer, Jena.

Glück, H., 1906. Alismataceae. In: Kirchner, O., Loew E., Schröter, C. (Eds.), Lebensgeschichte der Blütenpflanzen Mitteleuropas. Band I, Abteilung I. Eugen Ulmer Stuttgart, pp. 584-648.

Hulten, E., Fries, M., 1986. Atlas of North European vascular plants: north of the tropic of cancer. Koeltz Scientific Books, Königstein.

Ingelög, T., Thor, G., Hallingbäck, T., Andersson, R., Aronsson, M., 1991. Floravard jordbrukslandskapet. Skyddsvärda växter. SBT, Lund.

Jacobson, A., 2003. Diversity and phylogeography in Alisma (Alismataceae), with emphasis on Northern European taxa. Scripta Academica Lundensia. Ph.D. Thesis. University of Lund, Sweden.

Jones, R.A., 2006. Creeping water-plantain (Dyfr lyriad ymlusgawl), Baldellia ranunculoides subsp. repens (Lam.) A. Löve \& D. Löve in Wales. In: Leach, S.J. et al. (Eds.), Botanical Links in The Atlantic Arc. BSBI Conference Report No. 24, pp. 311-319.

Korneck, D., Schnittler, M., Vollmer, I., 1996. Rote Liste der Farn und Blütenpflanzen (Pteridophyta et Spermathophyta) Deutschlands. Schriftenreihe für Vegetationskunde 28, 21-187.

Lawalrée, A., 1959. Baldellia repens (Lamk.) van Ooststroom en Belgique. Bull. Jard Bot. Etat Brux. 29, 7-14

Lepš, J., Šmilauer, P., 2003. Multivariate Analysis of Ecological Data Using CANOCO. Cambridge University Press, Cambridge.

Lid, J., Lid, D.T., 2005. In: Elven, R. (Ed.) Norsk flora. 7th ed., Det Norske Samlaget, Oslo.

Lindblad, R., Stahl, B., 1989. Krypfloka (Apium inundatum) och flocksvalting (Baldellia ranunculoides) i norra Halland (SW Sweden). Svensk Bot. Tidskr. 83, 211-217.

Lindblad, R., Stahl, B., 1990. Revsvalting, Baldellia repens, i Norden. Svensk Bot. Tidskr. 84, 253-258. 
Loucougaray, G., Bonis, A., Bouzillé, J.B., 2004. Effects of grazing by horses and/or cattle on the diversity of coastal grasslands in western France. Biol. Conserv. 116, 59-71.

Maremmani, A., Bedini, S., Matosevic, I., Tomei, P.E., Giovannetti, M., 2003. Type of mycorrhizal associations in two coastal nature reserves of the Mediterranean basin. Mycorrhiza 13, 33-40.

Markgraf, F., 1981. Ordnung Helobiae. In: Hegi, G. (Ed.) Illustrierte Flora von Mitteleuropa. Band I, Teil 2, Dritte, völlig neubearbeitete Auflage. Paul Parey, Berlin, pp. 154-171.

Matthies, D., Bräuer, I., Maibom, W., Tscharntke, T., 2004. Population size and the risk of local extinction: empirical evidence from rare plants. Oikos 105, 481488.

McCune, B., Mefford, M.J., 1999. PC-ORD for Windows. MjM Software Design, Gleneden Beach, OR, USA.

Menges, E.S., 1991. The application of minimum viable population theory to plants. In: Falk, D.A., Holsinger, K.E. (Eds.), Genetics and Conservation of Rare Plants. Oxford University Press, Oxford, pp. 47-61.

Meusel, H., Jäger, E., Weinert, E., 1992. Vergleichende Chorologie der Zentraleuropäischen Flora. vol. 1-3. Gustav Fischer, Jena.

Moreno Saiz, J.C., Sainz Ollero, H., 1992. Atlas corologico de las Monocotiledoneas endemicas de la poninsila Iberica y Baleares. Bases para una politica de conservacion. Colleccion Tecnica. Icona, Madrid.

Moser, D.M., Gygax, A., Bäumler, B., Wyler, N., Palese, R., 2002. Liste Rouge des fougères et plantes à fleurs menacées de Suisse. BUWAL, Bern.

Murphy, K.J., 2002. Plant communities and plant diversity in softwater lakes of northern Europe. Aquat. Bot. 73, 287-324.

Pott, R., 1995. Die Pflanzengesellschaften Deutschlands. 2nd ed. Eugen Ulmer, Stuttgart.

Preston, C.D., Croft, J.M., 2001. Aquatic plants in Britain and Ireland. Harley Books, Colchester, Essex.

Roelofs, J.G.M., 1983. Impact of acidification and eutrophication on macrophyte communities in soft waters in The Netherlands. I. Field observations. Aquat. Bot. 17, 139-155.

Roelofs, J.G.M., 2002. Soft-water macrophytes and ecosystems: why are these so vulnerable to environmental changes? Aquat. Bot. 73, 285-286.

Roelofs, J.G.M., Schuurkes, J.A.A.R., Smits, A.J.M., 1984. Impact of acidification and eutrophication on macrophyte communities in soft waters in The Netherlands. II. Experimental studies. Aquat. Bot. 18, 389-411.
Romero, M.I., Rubinos, M., Ramil, P., 2003. Luronium natans, a rare species in the Iberian peninsula. Belg. J. Bot. 137, 85-90.

Sardinero Roscales, S., 1994. Etudio de la vegetation y de la flora del Macizo Occidental de la Sierra de Gredos (Sistema Central, Espana). Ph.D. Thesis. Faculty of Pharmacy, Departement of Botany II, University of Madrid.

Schoof-van Pelt, M.M., 1973. Littorelletea-a study of the vegetation of some amphiphytic communities of Western Europe. Stichting Studentenpers, Nijmegen.

Schubert, R., Hilbig, W., Klotz, S., 1995. Bestimmungsbuch der Pflanzengesellschaften Mittel und Nordostdeutschlands. Gustav Fischer, Stuttgart.

Sokal, R.R., Rohlf, F.J., 1995. Biometry: The Principles and Practice of Statistics in Biological Research, 3rd ed. Freeman and Co., New York.

Szankowski, M., Klosowski, S., 2001. Habitat conditions of the phytocenoses dominated by Luronium natans (L.) Rafin. in Poland. Hydrobiologia 455, 213-222.

Szankowski, M., Klosowski, S., 2006. Habitat variability of the Littorelletea uniflorae plant communities in Polish Lobelia lakes. Hydrobiologia 570, 117-126.

Ter Braak, C.J.F., Šmilauer, P., 2002. CANOCO reference manual and CanoDraw for Windows. User's Guide: Software for Canonical Community Ordination. (Version 4.5). Microcomputer Power, Ithaca NY, USA.

Triest, L., Vuille, F.-L., 1991. Isozyme variation in several seed collections and hybrids of Baldellia (Alismataceae). In: Triest, L. (Ed.), Isozymes in Water Plants. Opera Bot. Belg. 4, 37-48.

Tutin, T.G., Heywood, V.H., Burges, N.A., Moore, D.M., Valentine, D.H., Walters, S.M., Webb, D.A. (Eds.), 1980. Flora Europaea, vol. 1-5. Cambridge University Press, Cambridge.

Van Rompaey, E., Delvosalle, L., 1972. Atlas de la Flore Belge et Luxembourgeoise. Jardin Botanique National de Belgique, Bruxelles.

Vasconcellos, J.C., 1970. Novas combinaçoes nomenclaturais de plantas da flora Portuguesa. Bol. Soc. Broteriana, Ser. 2. 44, 81-83.

Vittoz, P., Wyss, T., Gobat, J.-M., 2006. Ecological conditions for Saxifraga hirculus in Central Europe: a better understanding for a good protection. Biol. Conserv. 131, 594-608.

Vuille, F.-L., 1988. The reproductive biology of the genus Baldellia (Alismataceae). Plant Syst. Evol. 159, 173-183.

Wigginton, M.J. (Ed.), 1999. British Red Data Books. 1. Vascular plants. Joint Nature Conservation Committee, Totnes, Devon.

Willby, N.J., Eaton, J.W., 1993. The distribution, ecology and conservation of Luronium natans (L.) Raf. in Britain. J. Aquat. Plant Manage. 31, 70-76. 